\title{
A comprehensive analysis on the impacting mechanism of innovation input on innova- tion performance
}

\author{
Hang WU \\ Business School, East China University of Political Science and Law, Shanghai, China
}

\begin{abstract}
Innovation has emerged as the main development strategy for Chinese high-tech firms. However, existing research mostly equals innovation input to $R \& D$ input and ignores to explore the impact of innovation input on innovation performance. This paper tends to establish the measurement framework of innovation input combining $\mathrm{R} \& \mathrm{D}$ and non-R\&D input, and tests the relationship between various innovation input and innovation performance. The results show that innovation performance is influenced by the overall improvement of innovation input. Therefore, it is necessary to increase innovation input comprehensively and specifically.
\end{abstract}

Keywords: Innovation input; Innovation performance; Optics Valley of China.

\section{Introduction}

With the globalization of economy, innovation has become the main rhythm in knowledge economy era ${ }^{[1]}$. Nowadays, all countries have been increasing the input in innovation, while our country reflects a strong trend. Firms in our country have increasingly consolidated their main position in innovation input and output. As we all know, the competence of a country or a industry finally embodies the competence of its firms. So it is significant to conduct some research on innovation input at the firm level, in order to correctly direct the input decision and enhance innovation capability of firms. As the supporting industries and the main source for economy growth, high-tech industries have been the key point among countries and regions. "Optics Valley of China" is a cluster area dominated by optoelectronic industry and the development of it significantly affects the two types of social construction and the implementation of central grow-up strategy. In light of the innovative statistics, "Optics Valley of China" has make great breakthrough in innovation input and output while it still falls far form the world famous high-tech zones, such as Silicon Valley. Therefore, it is necessary in theory to explore the relationship between innovation input and innovation performance of firms in "Optics Valley of China" in order to find out the high-tech firms' current situation, effectively direct the innovation input decision and enhance the competence of hightech firms.

\section{Literature review}

Existing research has paid enough attention to the relationship between innovation input and performance. On the one hand, foreign researchers has established systematical innovation theory. For example, Hall and Bagchi-Sen ${ }^{[2]}$ has examined the relationship between R\&D intensity, innovation output, and innovation performance in the context of Canadian bio-pharmaceutical industry. Hans and Almas ${ }^{[3]}$ has examined 
the relationship between innovation input including R\&D intensity and external cooperation input, knowledge capital and financial performance in Swedish manufacturing industry. Kaplinsky and Paulino ${ }^{[4]}$ also test the inpact of internationalization and $R \& D$ intensity on innovation performance, and find that internationalization enhances innovation performance through innovation capability.

On the other hand, domestic researchers introduces the innovation concept at a relative late period. Huang and Zhang ${ }^{[5]}$ empirically examine the impact of technological innovation input and management on competitiveness for Beijing manufacturing firms. Qi et al. ${ }^{[6]}$ explore the relationship between R\&D input intensity and competitiveness through regression analysis using the panel data of high-tech firms from 1995 to 2004. At the industrial level, Gong and $\mathrm{Qu}^{[7]}$ empirically analyze the impact of technological innovation input on the competitiveness of Chinese high-tech industry.

Although existing research has got great progess in the field of innovation measurement and the relationship between innovation input and innovation performance, the measurement on the innovation input and innovation performance of firms has not come to an agreement. Although there is clear definition and measurement index in relative literatures, many researchers still tend to use $R \& D$ input or $S \& T$ input to measure innovation input and use the number of patents applied or profit ability to measure innovation performance because it is difficult to get all the data. So there is little research from the multi-dimension view. In view of this, this paper explores the relationship between innovation input and innovation performance of high-tech firms in Optics Valley of China, based on the open innovation environment.

\section{Measurement of innovation input and innovation performance}

\subsection{Innovation input}

As for the measurement of innovation input, most researchers tend to use the index of R\&D expenditure and $R \& D$ staff, with a few researchers referring to the index of non- R\&D index, such as the input in buying and absorbing technology and instruments, establishing technological research center $^{[8]}{ }^{[9]}$. Although a lot of researchers have pointed out the importance of nonR\&D index, empirical research is still rare because of the difficulty in obtaining non$\mathrm{R} \& \mathrm{D}$ data.

In fact, $R \& D$ input just measures the $R \& D$ resources in innovation process, but some non- $R \& D$ resources is also important. As for the Chinese firms, $R \& D$ capability is relatively low, and firms have to increase innovative input in some aspects, such as introducing new technology and cooperate with other innovative agents, so it is necessary to comprehensively measure innovation input, including R\&D input and nonR\&D input.

Based on open innovation view, this paper tries to construct the measurement framework of innovation input, in terms of $\mathrm{R} \& \mathrm{D}$ input and non- $\mathrm{R} \& \mathrm{D}$ input (as shown in table 1). R\&D input includes the innovation input in basic research, applied research, experiment and development, R\&D personnel. Non-R\&D input includes the innovation input in external cooperation, science and technology center.

Table 1. Innovation input and performance of firms

\begin{tabular}{c|l|l}
\hline \multirow{4}{*}{$\begin{array}{c}\text { Innovation } \\
\text { input }\end{array}$} & \multirow{2}{*}{$\begin{array}{l}\text { R\&D } \\
\text { input }\end{array}$} & $\begin{array}{l}\text { Experiment and devel- } \\
\text { opment }\end{array}$ \\
\cline { 3 - 3 } & & R\&D personnel \\
\cline { 3 - 3 } & $\begin{array}{l}\text { Non-R\&D } \\
\text { input }\end{array}$ & \begin{tabular}{l} 
External cooperation \\
\cline { 2 - 3 }
\end{tabular} \\
\cline { 2 - 3 } & $\begin{array}{l}\text { Science and technolo- } \\
\text { gy center }\end{array}$ \\
\hline Innovation & Owned patents \\
\cline { 2 - 3 } performance & Net profit \\
\hline
\end{tabular}


As for the specific measurement method, each indicator is measured in terms of the ratio of innovation input indicator, such as applied research input intensity (AR) equals to applied research input / product sales; ratio of R\&D personnel (RP) equals to $R \& D$ personnel / total employees.

\subsection{Innovation performance}

Researchers have not come to an agreement in the measurement of innovation performance, such as profit, labor productivity, export ratio ${ }^{[10]}$. In this paper, we select patent and profit as measurement index because patent reflects the underlying strength and profit reflects the current strength.

\section{Empirical study}

\subsection{Data collection}

The research data comes from the innovation survey of China Optics Valley in 2006. We first select 777 high-tech firms among the surveying firms, and randomly choose 200 sampling firms. At last, we get 165 firms after eliminating 35 firms with incomplete data. The descriptive statistics of our sample is shown in table 2. Next, we will conduct correlation and regression analysis.

Table 2 Descriptive statistics

\begin{tabular}{c|c|c|c|c}
\hline & MIN & MAX & Mean & S.D. \\
\hline FS & 5 & 7250 & 268.21 & 692.47 \\
\hline NP & -9051 & 8378 & 5896.4 & 13490.6 \\
\hline OP & 0 & 6 & 1.39 & 1.333 \\
\hline RP & 0.044 & 0.753 & 0.236 & 0.119 \\
\hline RD & 0 & 0.124 & 0.042 & 0.027 \\
\hline BR & 0 & 0.100 & 0.003 & 0.009 \\
\hline AR & 0 & 0.087 & 0.014 & 0.015 \\
\hline ED & 0.001 & 0.111 & 0.026 & 0.020 \\
\hline EC & 0 & 0.086 & 0.009 & 0.014 \\
\hline ST & 0 & 4 & 0.74 & 0.943 \\
\hline 4.2. & Corr
\end{tabular}

\subsection{The correlation analysis}

Table 2 shows the Pearson correlation. The results show that all innovation input index except R\&D personnel, basic research are positively related to profit, all innovation input index except basic research are positively related to patent. So the improvement of innovation performance is determined by innovation input.

\subsection{Multiple regression analysis}

In order to examine the impacting mechanism of innovation input on innovation performance, we conduct two regression analysis with patent and profit as dependent variables. In the regression analysis, we take the firms size (FS) into consideration, with Mode 1 indicating small firms (employees number $\leqq 50$ ), Mode 2 indicating medium firms $(50<$ employees number $<$ 250), Mode 3 indicating large firms (employees number $\geqslant 250$ ).

The results in table 4 show that R\&D personnel is the most factors influencing owned patent for small firms, and experiment and development is the most factors influencing owned patent for large and medium sized firms. Surprisingly, external cooperation is not significant in all models which reflect that firms in China optics valley do not pay enough attention to use external resources.

The results in table 5 show that owned patent is positively related to profit in all models which highlights the importance of intellectual property protection. It also shows that R\&D personnel is the most factors for small firms, and experiment and development is the most factors for large and medium sized firms. Surprisingly, external cooperation is significant for large and medium sized firms, but not small firms. Except that, the number of science and technology center is significant for large firms. It demonstrates that large firms own more resources to attract and use external resources to innovate. 
Table 3 Descriptive statistics

\begin{tabular}{l|c|c|c|c|c|c|c|c|c|c}
\hline & 1 & 2 & 3 & 4 & 5 & 6 & 7 & 8 & 9 & 10 \\
\hline $1 . \mathrm{NP}$ & 1.00 & & & & & & & & & \\
\hline $2 . \mathrm{OP}$ & $0.61^{* *}$ & 1.00 & & & & & & & & \\
\hline $3 . \mathrm{RP}$ & 0.14 & $0.17^{*}$ & 1.00 & & & & & & & \\
\hline $4 . \mathrm{RD}$ & $0.54^{* *}$ & $0.58^{* *}$ & 0.06 & 1.00 & & & & & & \\
\hline 5. BR & 0.05 & 0.15 & $0.20^{*}$ & $0.27^{* *}$ & 1.00 & & & & & \\
\hline $6 . \mathrm{AR}$ & $0.27^{* *}$ & $0.29^{* *}$ & 0.11 & $0.62^{* *}$ & $0.38^{* *}$ & 1.00 & & & & \\
\hline 7. ED & $0.48^{* *}$ & $0.46^{* *}$ & -0.05 & $0.79^{* *}$ & -0.06 & 0.05 & 1.00 & & & \\
\hline 8.EC & $0.26^{* *}$ & $0.21^{* *}$ & 0.08 & 0.10 & 0.04 & 0.06 & 0.06 & 1.00 & & \\
\hline 9.ST & $0.48^{* *}$ & $0.50^{* *}$ & 0.06 & $0.41^{* *}$ & -0.01 & $0.20^{*}$ & $0.39^{* *}$ & $0.20^{* *}$ & 1.00 & \\
\hline 10.FS & $0.50^{* *}$ & $0.53^{* *}$ & 0.04 & $0.45^{* *}$ & 0.03 & $0.21^{* *}$ & $0.41^{* *}$ & $0.17 *$ & $0.61 * *$ & 1.00 \\
\hline
\end{tabular}

** indicates $\mathrm{p}<0.01, *$ indicates $\mathrm{p}<0.05$, Ns indicates not significant.

Table 4 Regression analysis of innovation input on owned patent performance

\begin{tabular}{c|c|c|c|c}
\hline & Model 1 & Model 2 & Model 3 & Model 4 \\
\hline Ratio of R\&D personnel & $0.634 * *$ & $\mathrm{Ns}$ & $\mathrm{Ns}$ & $0.125 *$ \\
\hline Ratio of basic research & $\mathrm{Ns}$ & $\mathrm{Ns}$ & $0.283 *$ & $\mathrm{Ns}$ \\
\hline Ratio of applied research & $\mathrm{Ns}$ & $\mathrm{Ns}$ & $\mathrm{Ns}$ & $0.161 *$ \\
\hline Ratio of experiment and development & $\mathrm{Ns}$ & $0.227 *$ & $0.491 * *$ & $0.342 * *$ \\
\hline External cooperation & $\mathrm{Ns}$ & $\mathrm{Ns}$ & $\mathrm{Ns}$ & $\mathrm{Ns}$ \\
\hline Number of science and technology center & $\mathrm{Ns}$ & $\mathrm{Ns}$ & $\mathrm{Ns}$ & $0.303 * *$ \\
\hline $\mathrm{F}$ & $4.794 * *$ & $2.252 *$ & $7.490 * *$ & $18.329 * *$ \\
\hline $\mathrm{R}^{2}$ & 0.385 & 0.164 & 0.608 & 0.410 \\
\hline Adjusted $\mathrm{R}^{2}$ & 0.304 & 0.091 & 0.527 & 0.388 \\
\hline $\mathrm{D}-\mathrm{W}$ & 1.794 & 2.168 & 2.158 & 1.715 \\
\hline
\end{tabular}

Model 1, model 2, model 3, model 4 indicate small, medium, large, and all firms respectively.

$* *$ indicates $\mathrm{p}<0.01$, * indicates $\mathrm{p}<0.05$, Ns indicates not significant

Table 5 Regression analysis of innovation input on net profit performance

\begin{tabular}{|c|c|c|c|c|}
\hline & Model 1 & Model 2 & Model 3 & Model 4 \\
\hline Ratio of R\&D personnel & $0.635 * *$ & Ns & Ns & Ns \\
\hline Ratio of basic research & Ns & Ns & Ns & Ns \\
\hline Ratio of applied research & Ns & Ns & Ns & $0.130 *$ \\
\hline Ratio of experiment and development & Ns & $0.227 *$ & $0.428 * *$ & $0.250 * *$ \\
\hline External cooperation & Ns & Ns & $0.556 * *$ & $0.125 *$ \\
\hline Number of science and technology center & Ns & Ns & $0.459 * *$ & $0.146 *$ \\
\hline Owned patents & $0.268 * *$ & $0.411 * *$ & $0.297 *$ & $0.358 * *$ \\
\hline $\mathrm{F}$ & $24.988 * *$ & $5.2 * *$ & $13.050 * *$ & $21.121 * *$ \\
\hline $\mathrm{R}^{2}$ & 0.795 & 0.349 & 0.765 & 0.485 \\
\hline Adjusted $\mathrm{R}^{2}$ & 0.764 & 0.282 & 0.707 & 0.462 \\
\hline D-W & 1.628 & 1.782 & 2.391 & 2.131 \\
\hline
\end{tabular}

Model 1, model 2, model 3, model 4 indicate small, medium, large, and all firms respectively.

$* *$ indicates $\mathrm{p}<0.01, *$ indicates $\mathrm{p}<0.05$, Ns indicates not significant 


\section{Conclusion}

Prior research on the relationship between innovation input and innovation performance has got much progress, but most research equals innovation input to $R \& D$ or scientific input, or take innovation input as a part of innovation capability. Based on existing research, this study aims to construct the comprehensive measurement framework of innovation input from the aspect of $R \& D$ and non-R\&D input, and empirically tests the impact of innovation input on innovation performance.

We discover that innovation performance is tightly related to innovation input. All innovation input index except basic research and external cooperation are positively related to patent performance, all innovation input index except R\&D personnel, basic research are positively related to profit performance. So the improvement of innovation performance is determined by the total enhancement of innovation input, which can direct the firms to promote innovation.

Our research still has some limitations. We just consider the individual impact of various innovation input, future research can deepen it by consider the joint impact of innovation inputs, and consider the contextual conditions.

\section{Acknowledgment}

This research was financially supported by China Post doctoral Science Foundation (2014M561452).

\section{References}

[1] R. C. M. Yam, J. C. Guan, An audit of technological innovation capabilities in Chinese firms: Some empirical findings in Beijing, China. Research Policy, vol.33, pp.1123-1140, 2004.

[2] L. A. Hall, S. Bagchi-Sen A study of $\mathrm{R} \& \mathrm{D}$, innovation, and business performance in the Canadian biotechnology industry. Technovation, vol.22, pp. 231-244, 2002.

[3] L. Hans, H. Almas, Knowledge capital and performance heterogeneity: A firmlevel innovation study. Int. J. Production Economics, vol.76, pp.61-85, 2002.

[4] R. Kaplinsky, A. S. Paulino. Innovation and competitiveness: Trends in unit prices in global trade. Oxford Development Studies, vol.33, pp.333-355, 2005.

[5] L. Huang, H. Zhang, X. Li, The technology innovation capability analysis of Beijing's manufacturing. Forum on Science and Technology in China. vol.4, pp. 41-44, 2005.

[6] Qi. Y, H. Lan, Luan, J. Technology strategy and coporate competence: An empirical analysis based on a comparison between domestic and foreign companies in Chinese high-tech industry. Science of Science and Management of S.\& T. . vol.10, pp.47-52, 2008.

[7] Y. Gong, N. Qu, Empirical research on effects of technological innovation capability on international competitiveness of Chinese high-tech industry. Technology Economics. vol.4, pp.13-18, 2008.

[8] K. Wakelin. Productivity growth and $\mathrm{R} \& \mathrm{D}$ expenditure in UK manufacturing firms. Research Policy vol.30, pp.1079-1090, 2001.

[9] H. Elena, The role of technological management as a source of innovation: Evidence from Spanish manufacturing firms. Research Policy vol.35, pp.1377-1388, 2006.

[10] J. Guan, N. Ma, Innovative capability and export performance of Chinese firms. Technovation, vol.23, pp.737747, 2003. 